\title{
The Influence of Posyandu Cadre Training on Knowledge and Attitudes in Efforts to Prevent Stunting in Karawang
}

\author{
Siti Sopiatun", Sri Maryati \\ ${ }^{1,2}$ School of Health Sciences Kharisma Karawang, Midwifery Study Program Indonesia. \\ *Corresponding authro email: karsi.nasya@gmail.com. srimaryati.hidayat@gmail.com
}

\begin{abstract}
Stunting is the delay in the growth process in children under five years of age as a result of chronic undernutrition so that children are too short for their age. Prevention efforts to prevent stunting include involving cadres in the First 1,000 days of life program which is the front line in posyandu services after village midwives, so that a good cadre role is needed in preventing stunting more effectively. The research design used a quasi experimental with Pretest and Posttest design. The samples obtained amount to 46 cadres and appropriate to inclusion and exclusion criteria. The data was analyzed using the Wilcoxon Signed Rank Test. The results showed that the frequency of knowledge and attitudes after training increased by $89.1 \%$ and $60.9 \%$. There is an effect of posyandu cadre training on knowledge in preventing stunting $(\mathrm{p}=0.000)$ but there was no effect of posyandu cadre training on attitudes in preventing stunting $(\mathrm{p}=0.371)$. In conclusion, the training that was carried out influenced the cadres knowledge more than the cadres attitudes.
\end{abstract}

Keywords: attitudes, cadre, knowledge, stunting

\section{INTRODUCTION}

Stunting is a the delay in the growth process in children under five years of age as a result of chronic undernutrition especially at in the First 1,000 days of life so that children are too short for their age (1). The undernutrition results from the baby in utero and in the few days after the baby is born, but stunting can detection in children after 2 years of age. Stunting can improve ilness, irregular body damage, sub-optimal brain development, decrease cognitive abilities and can kill the children (2). The causes of stunting include related to the health of mothers and children from an early age, both during pregnancy and the growing period of infants and toddlers. The most effective prevention to reduce incidence of stunting is by implementing the first 1,000 days of life, by implementing this program, the incidence of stunting can be effectively prevented (3).

The influence of nutrition, affection and brain stimulation greatly affects children on the incidence of stunting, because with good nutrition it will improve the quality of children's health. Some results of the study, it was explained that the prevalence of stunting was high, around $15 \%$ (4). Steps to prevent and reduce the incidence of stunting began several years ago, by involving posyandu cadres in the implementation of promotional activities for maternal and child health, especially stunting, these activities range from weighing, supplementary feeding and early detection, but the participation of these cadres has not been maximized because the information received is not good from health workers. Another problem is that cadres do not understand how to identify stunted children and the lack of quality and quantity of cadres (1).

The prevalence of stunting in Karawang Regency west Java in 2018 decreased to $11.7 \%$ compared to 2016 which was $13.7 \%$, Karawang Regency is still a priority place for the prevention and cure of stunting, there are 10 Community Health Centers have a high prevalence of stunting, with a percentage of $30 \%$, the survey of my research, previous researchers showed that $75 \%$ of the 125 posyandu cadres did not understand about stunting and prevention of stuquality. The results interviews with 35 posyandu cadres, it was found that the cadres had already cadre training and training related to providing additional food for children under five. training related to stunting has not been carried out because there is no training program held in Karawang, only counseling is provided by village midwives and the health promotion team to several cadres for a limited time.

Understanding this situation requires effective efforts prevent of stunting through training by increasing the quality of knowledge of posyandu cadres posyandu, based on the description above, the researcher will conduct the research on the influence of posyandu cadre training on knowledge and attitudes in efforts to prevent stunting in karawang.

\section{METHODS}

The research design used a quasi experimental with Pre-test and Post-test design. The samples obtained amount to 46 cadres and appropriate to inclusion 
and exclusion criteria. The training was conducted two times, the first week was divided into two sessions of pre-test and theoretical presentation, the second week of FGD and post-test. The data was analyzed using the Wilcoxon Signed Rank Test.

\section{RESEARCH FINDING AND DISCUSSION}

\begin{tabular}{|c|c|c|c|}
\hline & $\begin{array}{l}\text { Low ( not } \\
\text { schooling, } \\
\text { elementary } \\
\text { school, junior } \\
\text { hight school) }\end{array}$ & & \\
\hline 3 & $\begin{array}{l}\text { Long been a } \\
\text { cadre } \\
1-5 \text { years } \\
<1 \text { year } \\
\end{array}$ & $\begin{array}{l}26 \\
20\end{array}$ & $\begin{array}{l}56.5 \% \\
43.5 \%\end{array}$ \\
\hline 4 & $\begin{array}{l}\text { Training history } \\
\text { Already } \\
\text { Not yet }\end{array}$ & $\begin{array}{l}16 \\
30\end{array}$ & $\begin{array}{l}34.8 \% \\
65.2 \%\end{array}$ \\
\hline
\end{tabular}

\begin{tabular}{|l|l|c|c|}
\hline No & Variable & $\begin{array}{c}\text { Freq } \\
\text { uenc } \\
\mathbf{y}\end{array}$ & Percentage \\
\hline 1 & Ages & 12 & $26.1 \%$ \\
$\leq 20-35$ & 73.9 & $73.9 \%$ \\
\hline$>35$ & Education & 7 & $15.2 \%$ \\
& Hight (hight & $84.8 \%$ \\
school dan & 39 & \\
college) & \multicolumn{2}{|l}{} \\
\hline
\end{tabular}

From this result, the age of cadres were $>35$ years old is $73.9 \%$, education was in category low education at $84.8 \%$, had long been cadres for $1-5$ years and history of training $56.5 \%$.

TABLE 2. Description of Pre-Test and Post-Test Respondents' Knowledge

\begin{tabular}{|l|l|l|l|l|l|}
\hline \multirow{2}{*}{ No } & \multicolumn{2}{|c|}{ Variable } & \multicolumn{2}{c|}{ Pre Test } & \multicolumn{2}{c|}{ Post Test } \\
\cline { 3 - 6 } & & Frequency & Percentage & Frequency & Percentage \\
\hline 1 & Knowledge & 2 & $4.3 \%$ & 0 & \\
& Less & 24 & $52.2 \%$ & 5 & 0 \\
& Enough & 20 & $43.5 \%$ & 41 & 10.9 \\
& Good & & & & \\
\hline 2 & Attitude & 22 & 47.8 & 18 & 39.1 \\
& Negative & 24 & 52.2 & 28 & 60.9 \\
& Positive & \multicolumn{2}{|c|}{} & \\
\hline
\end{tabular}

It was found that the highest pre-test results were in enough knowledge and positive attitudes of $52.2 \%$ found in good knowledge and positive attitudes of $89.1 \%$ and $60.9 \%$. and $52.2 \%$, while the highest Post Test results were

TABLE 3. Effect of cadre training on knowledge in efforts to prevent stunting in Karawang

\begin{tabular}{|l|l|l|c|c|c|c|}
\hline \multirow{2}{*}{ No } & Variable & \multicolumn{2}{|c|}{ Pre Test } & \multicolumn{2}{c|}{ Post Tes } & \multirow{2}{*}{ Value $\mathrm{p}$} \\
\cline { 3 - 6 } & & $\mathrm{N}$ & $\%$ & $\mathrm{~N}$ & $\%$ & \\
\hline 1 & Knowledge & & & & & \multirow{2}{*}{0.000} \\
& Less & 2 & $100 \%$ & 0 & 0 & \\
& Enough & 24 & $82.8 \%$ & 5 & 17.2 & \\
& Good & 20 & $32.8 \%$ & 41 & $67.2 \%$ & \\
\hline
\end{tabular}

Based on the results with p. value $0.000<0.05$, it is concluded that there is an effect of posyandu cadre training on knowledge in preventing stunting in Karawang west java

TABLE 4. Effect of cadre training on attitudes in efforts to prevent stunting in Karawang

\begin{tabular}{|l|l|l|l|l|l|l|}
\hline \multicolumn{1}{|c|}{ No } & Variable & \multicolumn{2}{|c|}{ Pre Test } & \multicolumn{2}{c|}{ Post Tes } & \multirow{2}{*}{ Value $\mathrm{p}$} \\
\cline { 3 - 6 } & & & & & & \\
\hline \multirow{3}{*}{1} & Attitude & & & & & \multirow{2}{*}{0.371} \\
& Negative & 22 & 55.0 & 18 & 45.0 & \\
& Positive & 24 & 46.2 & 28 & 53.8 & \\
\cline { 3 - 6 } & & & & & & \\
\hline
\end{tabular}




\section{FROM THE RESULTS, WITH P VALUE $0.371>0.05$, IT IS CONCLUDED THAT THERE IS NO EFFECT OF POSYANDU CADRE TRAINING ON ATTITUDES IN PREVENTING STUNTING IN KARAWANG WEST JAVA. DISCUSSION}

The most cadres in category low education at $84.8 \%$, $56.5 \%$ had long been cadres for 1-5 years and history of training. Based on these characteristics, the ability of cadres in terms of knowledge and attitude is an important factor that cadres have in carrying out their duties to assist midwives and other health workers in reducing the incidence of stunting.

From this result, there is an effect of posyandu cadre training on knowledge in preventing stunting $(\mathrm{p}=0.000)$, the highest pre-test results were in enought knowledge and positive attitudes of $52.2 \%$ and 52.2\%, while the highest Post Test results were found in good knowledge and positive attitudes of $89.1 \%$ and $60.9 \%$. The aim of training is to increase certain knowledge and skills and to be able to carry out their responsibilities properly according to standards (5). The research is same by Sri Wahyuni explained that there was an increase in knowledge between before and after treatment, the increase in knowledge because the respondents had more opportunities to study posyandu material, with a time allocation between pre-test and post-test of approximately 1-3 weeks (6). This is same with the results of research conducted by Adistie. Empowerment activities in the form of one day of training divided into 3 sessions using the lecture, discussion and question and answer method as well as demonstrations and re-demonstrations by health cadres.

The results of the activity showed that there was an increase in the knowledge of health cadres before the activity was carried out as many as $61.3 \%$ of the cadres had good knowledge and after carrying out the activity it increased to $93.5 \%$. The results of statistical tests showed that there was a significant increase in knowledge of health cadres after intervention $(\mathrm{p}=0.000)(7)$.

From the results that there is no effect of Posyandu cadre training on attitudes in preventing stunting in
Karawang west Java, This is not in line by Sri Wahyuni which explains that there has been a significant increase in attitude between before and after training, the research was carried out using integrated media modules so that it makes it easier for cadres to understand their behavior. Besides that, cadres can get a better attitude improvement if there is support from people around them and have previous experience as a cadre (6). Research conducted by Greenspan, 2013 explains that training that is packaged according to cadre expectations is a good strategy in increasing cadre motivation (8). Motivation is all verbal, physical or psychological things that make someone do something with a response and is also a psychological process that reflects the interactions between attitudes, needs, perceptions and decisions that occur in a person. Increasing the positive attitude of respondents is the basis for forming consistency in becoming an active posyandu cadre (6).

Olaniran, etal research Community health workers (CHWs) can play to increase basic health services. CHWs can be categorised into two groups by education and pre-service training. The first group is paraprofessionals (individuals with some form of secondary education and subsequent informal training), and the second group is paraprofessionals (individuals with some form of secondary education and subsequent formal training lasting a few months to more than a year), the first group is on of the important for health worker to help community, The results of this study really explain that people who are involved in health promotion are very good to be developed because they are one of the forefront in inviting people to live better in the health sector (9). Result from Scott, Kerry Beckham, et al 2018 explain cadres are at the forefront of making approaches to society. Therefore supportive supervision, continuing education, and adequate logistical support and supplies are required for cadres. Effective training from training conducted by cadres can increase the sustainability of the program, and encourage collaboration between cadres and health system actors at higher levels, especially midwives. the study concluded. Evidence on the effectiveness of cadre training programs can help policy makers identify a range of issues for consideration (10). 


\section{CONCLUSION}

the training that was carried out influenced the cadres knowledge more than the cadres attitudes.

\section{ACKNOWLEDGMENT}

I would like to thank for my Institution of School of Health Sciences Kharisma Karawang, Indonesia for support and assistance in carrying out this research.

\section{REFERENCES}

[1] Direktorat Promosi Kesehatan RI. No Title. 2018.

[2] UNICEF. Improving Child Nutrition The Achievable Imperative for GlobalProgress. 2013.

[3] Sekertariatan wakil presiden Republik Indonesia. 100 Kabupaten/kota prioritas untuk intervensi anak kerdil (stunting). Jakarta. 2017;

[4] Ramos, C.V., Dumith, S.C., \& Cesar J. Prevalence and factors associated with stunting and excess weight in children aged 0-5 years from the Brazilian semi-arid region. J Pediatr. 2015;91(2):175-82.

[5] Notoatmodjo S. Promosi Kesehatan, Teori \& Aplikasi, ed. revisi 2010. Jakarta: Rineka Cipta. 2010.

[6] Sri Wahyuni, Johanes C. Mos2 US. Pengaruh pelatihan kader posyandudengan modul terintegrasi terhadap peningkatan pengetahuan,sikap dan keikutsertaan kader posyandu. J Ris Kebidanan Indones. 2019;3:95-101.

[7] Adistie F, Lumbantobing VBM, Maryam NNA. Pemberdayaan Kader Kesehatan Dalam Deteksi Dini Stunting dan Stimulasi Tumbuh Kembang pada Balita. Media Karya Kesehat. 2018;

[8] Greenspan JA, McMahon SA, Chebet JJ, Mpunga M, Urassa DP, Winch PJ. Sources of community health worker motivation: A qualitative study in Morogoro Region, Tanzania. Hum Resour Health. 2013;

[9] Olaniran A, Smith H, Unkels R, Bar-Zeev S, van den Broek N. Who is a community health worker? - A systematic review of definitions. Global Health Action. 2017.
[10] Scott K, Beckham SW, Gross M, Pariyo G, Rao KD, Cometto G, et al. What do we know about community-based health worker programs? A systematic review of existing reviews on community health workers. Human Resources for Health. 2018. 